around the globe. Staff can help students in those countries to explore different UK universities' specialities, seek scholarships and funding support, and learn about life in different UK cities. Likewise, EducationUSA, a network run by the US Department of State, has more than 450 offices operating in 170 countries. Its staff aims to inform prospective students about the diverse education opportunities at more than 400,000 US colleges and universities.

When choosing a university, students should also consider the cost, the climate, the size of the city, the local amenities and the cultural diversity, say university advisers. "We find that many foreign nationals value the cultural diversity found in all the major UK cities," says Catherine Marston, a policy adviser at Universities UK.

Metropolitan centres aren't the only ones to value cultural diversity. Purdue University in West Lafayette, Indiana, for example, has an 'international friendship programme' that matches community residents with new students. Some 175 students were matched last autumn. Purdue's Office of International Students and Scholars organizes a variety of social and cultural outings - from basketball games to Amish-country field trips - for the approximately $40 \%$ of Purdue's graduate students who come from abroad. "We try to give our international students a rich cultural experience," says programme director Michael Brzezinski.

\section{The funding factor}

Finding a way to pay for a rich academic experience is the next hurdle. Many foreign graduate students secure funding through their host country or through a research or teaching fellowship from the department of the university they plan to attend. Purdue funds $70 \%$ of its students through this mechanism, which again highlights the benefit of establishing departmental contacts.

Partnership schemes designed to support individual nationalities, such as Commonwealth scholarships that aim to attract students from Singapore or Australia to the United Kingdom, or partnerships with companies looking to target specific research areas, also exist at most universities. But government-sponsored scholarships, such as the UK Chevening programmes or the US Fulbright programmes, are among the most prestigious awards open to foreign nationals. Dugarjav jumped at the chance to apply for a fully funded $\mathrm{PhD}$ through the International Fulbright Science and Technology Award. The programme gives out roughly 45 awards each year to outstanding foreign students in fields from neuroscience to astronomy. The three-year awards pay a monthly stipend plus tuition and fees, books, equipment, travel, research and professional conference allowances. After that, the universities continue their support until the students complete their programmes. Currently, $40 \%$ of Fulbright scholars do science research.

But it's not just about academia. College advisers make it clear that admission committees are interested in a person's leadership qualities. "Scores and grades speak for themselves, but students need to make sure their personality, energy and passion for their research field are evident on the application," says Danielle Guichard-Ashbrook, associate dean for international students at the Massachusetts Institute of Technology in Cambridge. Foreign students, especially those in an area where progress is largely determined by test scores, may not appreciate the need to reveal their motivations, says Guichard-Ashbrook.

\section{Mixed feelings}

Once at university, students should be prepared to experience a range of emotions. Exploring cultural differences makes the first few weeks in a new country exciting. But once the excitement ebbs, typically after about two months, many students become frustrated, both culturally and academically.

"All students go through culture shock it's very normal," says Joanna Shearer, head of international student recruitment at Imperial

\section{TIPS FOR SUCCESS}

DO apply for a student visa as soon as possible. The visa process in both the United States and Britain, for example, has undergone revisions in recent years. Lengthy delays are no longer the norm but can occur.

DON'T assume that student visas are general and allow entry to any university at which you have been accepted. Student visas are site-specific. New US and UK regulations, designed to track foreign students more effectively, grant visas to one institution.

DO get involved with the student club dedicated to your particular nationality.

DON'T let that be your only connection to other students. Explore other ways to connect with fellow students.

DO seek academic help or tutoring if needed.

DON'T think that asking for help is a sign of weakness. International student offices provide a number of support programmes to help students be successful.
College London. She says it is important to keep a sense of humour, especially with respect to cultural differences. Her office, as with those at many universities, offers a tutorial of regional slang terms for incoming students as part of their orientation. "The students who are successful understand that there will be differences and will come with a curiosity to explore those differences," says John Greisberger, director of the International Center at the University of Michigan in Ann Arbor. He says good schools offer programmes that help students adjust culturally and in other ways.

John Pearson, director of Stanford University's Bechtel International Center in Palo Alto, California, has found that foreign students appreciate a clear explanation of the rights and responsibilities they must uphold as part of their foreign student status in the United States. For example, students must obtain a social security number and maintain an accurate home address in the university system in order to conform with federal regulations requiring universities to keep track of foreign students. (See 'Tips for success.)

Nonetheless, students must find a way to balance their academic and social pursuits, notes Guichard-Ashbrook. "The most successful and happiest students are the ones who have a life outside the lab," she says. Martin Petricic, a Croatian PhD student in ocean engineering at the University of California at Berkeley, has continued his lifelong hobby of fencing in an effort to meet more people. Petricic views his time in the United States as an opportunity to make contacts. "These contacts may open doors to future research collaborations," he says.

For Dugarjav, making the most of her US graduate experience means finding a way to return to Mongolia to not only conduct research, but also to help educate the younger generation. "I would really like to use what I have learned," she says, "to improve the education system back home.”

Virginia Gewin is a science writer based in Portland, Oregon.

\section{Clarification}

The Feature 'Seeds of collaboration' (Nature 461, 1158-1159; 2009) omitted that the Searle family topped up the US\$5 million it gave to establish the Chicago Biomedical Consortium with a further $\$ 15$ million. In addition, it should be made clear that the University of Chicago is the sole institution managing Argonne National Laboratory. 